\title{
KETAHANAN BANK MANDIRI SYARIAH MELALUI UJI NPF DAN ROA PADA PERIODE KRISIS GLOBAL TAHUN 2008-2016 DARI DAMPAK PERTUMBUHAN EKONOMI, INFLASI, DAN SUKU BUNGA
}

\author{
M. Shaiful Umam \\ Gresik \\ shaiful.umam31@gmail.com
}

\begin{abstract}
Bank Syariah Mandiri is a banking institution established by Bank Mandiri. This study aims to analyze the effect of economic growth, inflation, and interest rates on the flexibility of Bank Mandiri Syariah as measured by ROA (return on assets) and NPF (bad performance). This research is a quantitative study with the independent variables of economic growth, inflation and interest rates. The dependent variable is the return on assets (ROA) and risk of financing (no financing is made). The results of this study indicate that: (1) the variable Economic Growth Rate (IPI) has a negative effect on the Return on Assets (ROA) of Bank Syariah Mandiri for the period 2008-2016; The Bank's Return on Assets (ROA) during the period 2008-2016 had a negative impact; (2) The inflation rate (CPI) has a negative effect on the return on assets (ROA) of Bank Syariah Mandiri during 2008-2016; (3) Interest rates (SBI) have a negative effect on return on assets of Bank Syariah Mandiri during 2008-2016 (ROA) does not have a significant negative effect; (4) Economic growth rate (IPI) has a negative effect on non-performing financing (NPF) of Bank Syariah Mandiri from 2008 to 2016; (5) The inflation rate (CPI) has a negative effect on Bank Syariah Mandiri 2008 - Non performing financing (NPF) 2016 has a negative impact; (6) Interest rates (SBI) will not have a significant negative effect on the Non-Performing Loan (NPF) of Bank Syariah Mandiri for the period 2008-2016.
\end{abstract}

Keywords: Global Crisis; Banking Resilience; Inflation; Interest Rate.

Abstrak: Bank Syariah Mandiri adalah lembaga perbankan yang didirikan oleh Bank Mandiri. Penelitian ini bertujuan untuk menganalisis pengaruh pertumbuhan ekonomi, inflasi, dan suku bunga terhadap fleksibilitas Bank Mandiri Syariah yang diukur dengan ROA (return on asset) dan NPF (bad performance). Penelitian ini merupakan penelitian kuantitatif dengan variabel independen pertumbuhan ekonomi, tingkat inflasi dan tingkat suku bunga. Variabel dependen adalah pengembalian aset (ROA) dan risiko pembiayaan (tidak ada pembiayaan yang dilakukan). Hasil penelitian ini menunjukkan bahwa: (1) Variabel Economic Growth Rate (IPI) berpengaruh negatif terhadap Return On Asset (ROA) Bank Syariah Mandiri periode 2008-2016; Return on Asset (ROA) Bank selama periode periode 2008-2016 berdampak negatif; (2) Tingkat inflasi (CPI) berpengaruh negatif terhadap return on asset (ROA) Bank Syariah Mandiri selama tahun 2008-2016; (3) Suku bunga (SBI) berpengaruh negatif terhadap return on asset Bank Syariah Mandiri selama tahun 2008-2016 (ROA) tidak memiliki pengaruh negatif yang

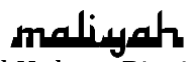

Jurnal Hukum Bisnis Islam

Volume 9 Nomor 2, Desember 2019

p-ISSN: 2088-4869/ e-ISSN: 2597-4351 
signifikan; (4) Tingkat pertumbuhan ekonomi (IPI) berpengaruh negatif terhadap non-performing financing (NPF) Bank Syariah Mandiri dari tahun 2008 hingga 2016; (5) Tingkat inflasi (IHK) berpengaruh negatif pada Bank Syariah Mandiri 2008- Non performing financing (NPF) 2016 berdampak negatif; (6) Suku bunga (SBI) tidak akan berpengaruh negatif signifikan terhadap Non Performing Loan (NPF) Bank Syariah Mandiri periode 2008-2016.

Kata Kunci: Krisis Global; Ketahanan Perbankan; Inflasi; Suku Bunga.

\section{Pendahuluan}

Berdirinya bank syariah di Indonesia diawali oleh adanya beberapa fatwa dari organisasi keislaman di Indonesia tentang bunga bank. Di antaranya adalah fatwa organisasi Muhammadiyah melalui hasil keputusan Tarjih tahun 1968 dan 1972, fatwa Nahdlatul 'Ulama melalui hasil keputusan Lajnah Bahsul Masa'il tahun 1982, fatwa MUI No.1 tahun 2004 tentang bunga bank dan fatwa terbaru hasil keputusan Tarjih dan Tajdid Muhammadiyah No.8 tahun 2006 yang juga mendorong tumbuh kembangnya perbankan syariah di Indonesia. Pemerintah juga memberikan dukungan terhadap eksistensi perbankan syariah di Indonesia. Hal ini terbukti dengan diubahnya UU No. 7 Tahun 1992 menjadi UU No.10 Tahun 1998 tentang Bank Indonesia. Selain itu, pemerintah juga telah mengeluarkan regulasi terbaru yang mengatur secara khusus mengenai perbankan syariah melalui UU No. 21 Tahun 2008.

Adanya dukungan dari lembaga keagamaan dan pemerintah tersebut, sejak tahun 2007 secara kuantitatif lembaga keuangan syariah mengalami perkembangan yang sangat baik perbankan syariah mengalami peningkatan dari tahun ke tahun. Pada tahun 2007 perkembangan Bank Umum Syariah (BUS) mengalami pertumbuhan sebanyak 7 buah. Perbankan konvensional yang membuka Unit Usaha Syariah (UUS) berkurang dari 26 menjadi 23 bank. Hal ini berarti bahwa UUS yang ada pada bank konvensional telah dikonversi menjadi BUS. Dalam perkembangan perbankan syariah yang semakin pesat tersebut, di akhir tahun 2008, industri perbankan nasional dihadapkan adanya krisis global yang terjadi diberbagai belahan dunia, termasuk di Indonesia. Akibatnya, antara lain adalah pada oktober 2008 terdapat tiga

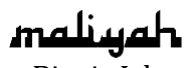


bank besar BUMN yang meminta bantuan likuiditas, masingmasing sebesar Rp 5 triliun. ${ }^{1}$

Sejak terjadinya krisis keuangan, praktis semua perhatian tertuju pada performa dari keuangan islam khususnya pada sektor perbankan syariah. Yang kemudian dikorelasikan dengan stabilitas finansial dan lebih spesifiknya perhatian terfokus pada ketahanan perbankan syariah selama krisis berlangsung. Beberapa pakar bisnis dan akademisi berpendapat bahwa asset based dan risk sharing pada perbankan syariah secara alami menjadikan perbankan syariah tahan terhadap guncangan krisis keuangan beberapa tahun lalu. ${ }^{2}$

Bank Syariah Mandiri merupakan salah satu lembaga perbankan besar di Indonesia yang dibentuk oleh Bank Mandiri. Bank Syariah Mandiri hadir, tampil dan tumbuh sebagai bank yang mampu memadukan idealisme usaha dengan nilai-nilai rohani, yang melandasi kegiatan operasionalnya. Harmoni antara idealisme usaha dan nilai-nilai rohani inilah yang menjadi salah satu keunggulannya dan hadir untuk bersama membangun Indonesia menuju yang lebih baik.

Pembiayaan merupakan salah satu kegiatan bank yang secara langsung berkaitan dengan sektor riil untuk mengantispasi kondisi perekonomian yang tidak stabil sebagai tolok ukur perkembangan Bank Syariah. Investasi yang dilakukan oleh berbagai pihak banyak mengandalkan pembiayaan dari perbankan syariah. Sementara itu, setiap pembiayaan yang disalurkan oleh bank syariah tersebut mengandung risiko. Dengan demikian, semakin tinggi pembiayaan yang diberikan maka semakin tinggi pula risiko pembiayaan yang akan ditanggung bank syariah. Indikator yang menunjukkan kerugian akibat risiko pembiayaan adalah

\footnotetext{
${ }^{1}$ Humas Bank Indonesia, Krisis Global Dan Penyelamatan Atas Sistem Perbankan Indonesia (Jakarta: Bank Indonesia, 2010).8

2 Maher Hasan and Jemma Dridi, "The Effect of Global Crisis On Islamic and Conventional Banking: A Comparative Study," IMF Working Paper, n.d.7
} 
kerugian akibat risiko pembiayaan yang tercermin dari besarnya Non Performing Financing (NPF). NPF adalah rasio antara pembiayaan bermasalah dengan total pembiayaan yang disalurkan oleh bank. Semakin tingginya pembiayaan dari bank yang disalurkan kepada masyarakat, semakin besar juga peluang terjadinya pembiayaan bermasalah. Counterparty merupakan pihak mitra yang dalam hal ini merujuk pada para nasabah yang memanfaatkan pembiayaan dari perbankan syariah. Setiap pembiayaan yang diberikan perbankan syariah tersebut memiliki risiko pembiayaan. Dalam hal ini risiko pembiayaan diukur dengan rasio Non Performing Financing (NPF).

Berdasarkan masalah yang terjadi dalam pembiayaan PT. Bank Syariah Mandiri. PT. Bank Syariah Mandiri terus mengalami fluktuasi persentase pembiayaan bermasalah (NPF) yaitu dari tahun 2011 sebesar 3,30\% dan mengalami penurunan di tahun 2012 sebesar 2,82\%, kemudian mengalami peningkatan NPF yang sangat melonjak yakni pada tahun 2013,2014, dan 2015 dengan persentase 3,44\%, 4,88\%, dan 6,77.3 Kondisi ini menunjukkan bahwa PT. Bank Syariah Mandiri memiliki kualitas yang tidak baik yang artinya mencerminkan kondisi bank yang secara umum tidak sehat sehingga dinilai tidak mampu menghadapi pengaruh negatif yang signifikan dari perubahan kondisi bisnis dan faktor eksternal lainnya. Selain itu menurut peraturan Bank Indonesia, rasio NPL total kredit hanya boleh kurang dari 5\%. Sebagai salah satu bank, PT.Bank Syariah Mandiri punya cara tersendiri agar tak terjebak problem pembiayaan bermasalah. ${ }^{3}$

Ketika ada kenaikan harga-harga ini memberikan tekanan pada ekonomi masyarakat terutama bagi mereka yang menjadi debitur (mudharib) perbankan syariah. Jika inflasi terjadi pada saat pendapatan masyarakat tetap atau menurun, maka hal ini dapat memperparah risiko pembiayaan yang

\footnotetext{
3 Peraturan Bank Indonesia No. 13/1/PBI/2011, Peningkatan Tingkat Kesehatan Bank Umum Pasal 9 (7).
} 
dihadapi perbankan syariah, sebab kemampuan pengembalian pembiayaan oleh debitur turut menurun. Hal tersebut diperkuat dengan hasil penelitian Linda, ${ }^{4} \mathrm{dkk}$ yang menemukan bahwa inflasi, dan tingkat suku bunga secara individual berpengaruh signifikan terhadap non performing loan pada PT Bank Tabungan Negara (Persero) Cabang Padang, sedangkan kurs tidak berpengaruh signifikan terhadap non performing loan pada PT Bank Tabungan Negara (Persero) Cabang Padang.

Indikator lainnya dalam melihat pertumbuhan Perbankan Syariah dengan digunakannya ukuran kinerja keuangan untuk mengetahui peningkatan nilai perusahaan. Faktor makro ekonomi merupakan salah satu faktor yang juga menyumbang pengaruh terhadap kinerja keuangan. ${ }^{5}$ Menurut Ongore ${ }^{6}$ stabilitas kebijakan makro ekonomi, produk domestic bruto, inflasi, suku bunga dan ketidakpastian politik juga merupakan variabel ekonomi makro lainnya yang mempengaruhi kinerja bank. Faktor makroekonomi merupakan salah satu faktor yang datang dari luar yang sifatnya diluar kekuasaan bank, sehingga kebijakan pemerintah secara tidak langsung akan mempengaruhi tingkat kesehatan industri perbankan di Indonesia.

Studi ini termasuk dalam jenis metode penelitian kuantitatif, karena menggunakan data penelitian yang berupa angka-angka dan analisis dengan menggunakan statistik. ${ }^{7}$ Sifat penelitian ini adalah explanatory research, yang berarti

\footnotetext{
${ }^{4}$ Linda, "Pengaruh Inflasi, Kurs Dan Tingkat Suku Bunga Terhadap Non Performing Loan Pada PT. Bank Tabungan Negara (PERSERO) Tbk Cabang Padang," Journal of Economic and Economic Education Vol.3 No.2 (2015): 137-144.

${ }^{5}$ Rismon $\mathrm{H}$ and Henny Setyo L, "Pengaruh Faktor Intenal Dan Eksternal Bank Terhadap Kinerja Bank Di Perusahaan Perbankan Di Bursa Efek Indonesia," Jurnal Manajemen Trisakti Vol2 No,1 (2015): 16.

${ }^{6}$ V.O Ongore, "The Relationsip Between Ownership Structure and Firm Performance: An Empirical Analysis of Listed Companies in Kenya," Africal Journal of Bussines Manajement (2011).

7 Sugiyo, Metode Penelitian Kuantitatif Kualitatif Dan $R \& D$ (Bandung: Alfabeta, 2010).13
} 
menjelaskan hubungan kausal antara variabel-variabel yang ada melalui pengujian hipotesis, dan menguji data sampel yang kemudian hasilnya digeneralisasi terhadap populasi. ${ }^{8}$ Tujuan yang ingin dicapai dalam penelitian ini ialah untuk menguji (1) pengaruh Tingkat Pertumbuhan Ekonomi, Tingkat Inflasi, Tingkat Suku Bunga, dan Exchange rate (Nilai Tukar) terhadap daya tahan perbankan syariah yang diukur dari ROA (Return On Asset); dan (2) pengaruh Tingkat Pertumbuhan Ekonomi, Tingkat Inflasi, Tingkat Suku Bunga, dan Exchange rate (Nilai Tukar) terhadap daya tahan perbankan syariah yang diukur dari NPF (Non Performing Financing).

Jenis data yang digunakan dalam penelitian ini merupakan data sekunder yang bersifat kuantitatif dan merupakan data triwulan untuk periode 2008-2016. Sumber data dalam penelitian ini adalah laporan laba rugi, laporan neraca dan laporan kualitas aktiva produktif triwulanan 4 Bank Umum Syariah Devisa yang ada di Indonesia. Data yang diteliti diambil dari tahun 2008 sampai dengan 2016. Jumlah unit yang diteliti adalah sebanyak 144 laporan keuangan Bank Umum Syariah Devisa. Adapun data yang digunakan merupakan kombinasi antara data cross section dengan data bertipe time series. Data gabungan ini disebut juga dengan data panel (pooled data). Hal ini dilakukan karena data panel memiliki beberapa keunggulan.

\section{Perbankan Syariah}

Menurut Undang-Undang RI Nomor 10 tahun 1998 tentang perbankan, yang dimaksud dengan bank adalah "Badan usaha yang menghimpun dana dari masyarakat dalam bentuk simpanan dan menyalurkannya kepada masyarakat dalam bentuk kredit atau bentuk-bentuk lainnya dalam rangka meningkatkan taraf hidup rakyat banyak". ${ }^{9}$

\footnotetext{
${ }^{8}$ Ibid.16

9 Dahlan Siamat, Manajemen Lembaga Keuangan Edisi (Jakarta: lembaga Penerbit FE, 2001).33
} 
Perbankan syariah adalah suatu sistem perbankan yang dikembangkan berdasarkan syariah islam. Usaha pembentukan sistem ini didasari oleh larangan dalam agama islam untuk memungut maupun meminjam dengan bunga atau yang disebut dengan riba serta larangan investasi untuk usahausaha yang dikategorikan haram, dimana hal ini tidak dapat dijamin oleh sistem perbankan konvensional.

Karakteristik sistem perbankan syariah yang beroperasi berdasarkan prinsip bagi hasil memberikan alternatif sistem perbankan yang saling menguntungkan bagi masyarakat dan bank, serta menonjolkan aspek keadilan dalam bertransaksi, investasi yang beretika, mengedepankan nilai-nilai kebersamaan dan persaudaraan dalam berproduksi, serta menghindari kegiatan spekulatif dalam bertransaksi keuangan. Dengan menyediakan beragam produk serta layanan jasa perbankan yang beragam dengan skema keuangan yang lebih bervariatif, perbankan syariah menjadi alternatif sistem perbankan yang kredibel dan dapat digunakan oleh seluruh golongan masyarakat Indonesia tanpa terkecuali.

Undang-Undang Nomor 30 tahun 1998 yang telah dikeluarkan sebagai tindak lanjut dari Peraturan Pemerintah Nomor 72 tahun Undang-Undang Nomor 10 tahun 1998 tersebut, Bank Indonesia sebagai otoritas perbankan mengeluarkan beberapa ketentuan berkaitan dengan perbankan syariah, yaitu Bank Umum syariah, BPR Syariah, dan Bank Konvensional yang membuka usaha Syariah.

\section{Ketahanan Perbankan Syariah}

Ketahanan (Daya Tahan) atau kondisi kesehatan keuangan dan non keuangan bank berdasarkan prinsip syariah merupakan kepentingan semua pihak terkait, baik pemilik, pengelola bank, masyarakat pengguna jasa bank, Bank Indonesia selaku otoritas pengawasan bank maupun pihak lainnya. Kondisi bank tersebut dapat digunakan oleh pihakpihak tersebut untuk mengevaluasi kinerja bank dalam menerapkan prinsip kehati-hatian, kepatuhan terhadap prinsip 
syariah, kepatuhan terhadap ketentuan yang berlaku dan manajemen risiko.

Meningkatnya produk dan jasa perbankan syariah yang semakin kompleks dan beragam akan meningkatkan eksposur risiko yang dihadapi bank berdasarkan prinsip syariah. Perubahan eksposur risiko dan penerapan manajemen risiko akan mempengaruhi profil risiko yang selanjutnya berakibat pada kondisi bank berdasarkan prinsip syariah secara keseluruhan. Penilaian tingkat kesehatan bank dan penilaian manajemen risiko dibedakan namun terdapat perpotongan antara keduanya. Dalam penilaian tingkat kesehatan telah memasukkan risiko yang melekat pada aktivitas bank (inherent risk) yang merupakan bagian dari proses penilaian manajemen risiko. ${ }^{10}$

Indikator penilaian tingkat kesehatan (ketahanan) bank syariah dapat dilakukan diukur melalui nilai NPF (Non Performing Financing), ROE (Return on Equity) serta ROA (Return on Asset).

1. NPF (Non Performing Financing)

NPF merupakan rasio pembiayaan bermasalah suatu bank syariah terhadap total seluruh pembiayaan yang diberikan bank. Apabila nilai NPF semakin besar, maka bank dalam keadaan tidak sehat.

2. ROA (Return on Asset)

ROA merupakan rasio yang digunakan untuk mengukur kemampuan manajemen bank dalam memperoleh keuntungan secara keseluruhan. Semakin besar rasio ROA suatu bank, semakin besar pula tingkat keuntungan yang dicapai bank tersebut dan semakin baik pula posisi bank tersebut dari segi penggunaan aset.

3. ROE (Return on Equity)

ROE merupakan rasio yang digunakan untuk mengukur kinerja manajemen bank dalam mengelola modal yang tersedia untuk menghasilkan laba setelah pajak. Semakin

10 Bank Indonesia, Laporan Tahunan, 2005-2010. 
tinggi rasio ini berarti bahwa tingkat keuntungan yang dicapai bank semakin besar sehingga kemungkinan suatu bank dalam kondisi bermasalah semakin kecil.

Variabel moneter yang digunakan dalam penelitian ini adalah pertumbuhan ekonomi, tingkat inflasi dan tingkat suku bunga. Pemilihan keempat variabel diatas dikarenakan variabel tersebut merupakan indikator makroekonomi, yang mana kestabilan ketiga variabel di atas dapat berpengaruh pada ketahanan perbankan syariah.

1. Pertumbuhan Ekononmi

Pertumbuhan ekonomi dalam suatu Negara dalam penelitian ini dilihat dari Industrial Production Index (IPI). Pertumbuhan indeks ini seiring dengan perkembangan ekonomi. Biasanya bila perekonomian bertumbuh dan berkembang, nilai indeks produksi suatu negara pun mengalami peningkatan.

2. Tingkat Inflasi

Inflasi adalah kecenderungan dari harga - harga untuk naik secara umum dan terus menerus. ${ }^{11}$ Sementara itu Inflasi sebagai kenaikan tingkat harga rata-rata, dan harga adalah tingkat dimana uang dipertukarkan untuk mendapatkan barang atau jasa. Dengan demikian kenaikan suatu barang atau beberapa barang pada saat tertentu yang hanya sementara tidak dapat dikatakan sebagai inflasi. Inflasi merupakan gejala ekonomi yang selalu muncul dan melanda hampir semua negara. Salah satu fokus utama kebijakan ekonomi suatu negara adalah mengendalikan inflasi. Hal ini karena inflasi yang tinggi dan berlangsung lama dapat berdampak buruk pada perekonomian suatu negara. ${ }^{12}$

3. Tingkat Suku Bunga

Tingkat suku bunga menyatakan tingkat pembayaran atas pinjaman atau investasi lain, di atas perjanjian pembayaran

11 Boediono, Ekonomi Moneter (Yogyakarta: BPFE, 1998).

12 N Gregory Mankiw, Makroekonomi (Jakarta: Penerbit Erlangga, 2007).66 
kembali yang dinyatakan dalam presentase tahunan. ${ }^{13}$ Suku bunga terbagi menjadi dua, yaitu suku bunga nominal dan suku bunga riil. Tingkat suku bunga nominal adalah tingkat suku bunga yang dibayar bank atau investor. Tingkat suku bunga riil adalah tingkat suku bunga yang diukur dengan kenaikan daya beli atau sudah memperhatikan nilai inflasi.

\section{Krisis Keuangan Global}

Menurut Kamus Besar Bahasa Indonesia, "krisis" adalah keadaan yang berbahaya; parah sekali; genting. 14 "Keuangan" adalah perihal yang berhubungan dengan uang; keadaan dan urusan uang. 15 Dan "global" adalah secara umum dan keseluruhan; secara bulat; meliputi seluruh dunia. ${ }^{16}$

Jadi krisis keuangan global adalah suatu kondisi terjadi perubahan tajam keadaan ekonomi dimana berbagai langkah pengendalian sudah tidak lagi mampu menahan gejolak pada sektor keuangan, yang akan segera diikuti dengan kontraksi ekonomi secara menyeluruh dan berdampak luas. Jika krisis masih terisolasi pada sektor keuangan saja, maka dikatakan situasi belum sampai menjalar pada krisis ekonomi. Tetapi manakala gejolak di sektor keuangan telah mengganggu kinerja makro ekonomi, seperti inflasi yang parah, pertumbuhan yang melambat, dan lain sebagainya, maka kondisi ini telah merambat pada situasi krisis ekonomi. ${ }^{17}$

Dalam konteks globalisasi, sesuatu peristiwa penting yang terjadi di salah satu bagian dunia akan berimbas ke bagian lain. Hal ini berlaku juga pada krisis keuangan. Jika sebuah negara mengalami krisis maka akan berdampak pada negara lain. Jika dampak yang ditimbulkan tersebut luas dan

\footnotetext{
13 R Dornbusch, Macroeconomics (New York: Mc Graw Hill Inc, 2008).31

14 Departemen Pendidikan Nasional, Kamus Besar Bahasa Indonesia Pusat Bahasa, edisi ke-4. (Jakarta: PT. Gramedia Pustaka Utama, 2008).77

15 Ibid.81

16 Ibid.86

17 Ibid. 94
} 
dialami oleh hampir semua negara di dunia maka krisis ini disebut krisis keuangan global.

Salah satu contoh krisis keuangan global adalah krisis keuangan global 2008 yang bersumber dari subprime mortgage crisis di Amerika Serikat (AS) bermutasi menjadi krisis keuangan global. ${ }^{18}$ Hal tersebut dikarenakan proporsi sumbangan perekonomian AS terhadap produksi global mencapai 25\%, sehingga ketika terjadi perlambatan perekonomian di AS maka perekonomian global pun akan cenderung menurun. ${ }^{19}$

\section{Deskripsi Variabel Penelitian}

Analisis statistik deskriptif memberikan informasi mengenai deskripsi dari variabel yang digunakan dalam penelitian. Informasi tersebut disajikan dari nilai rata-rata dari masing-masing variabel Tingkat Pertumbuhan Ekonomi (IPI), Tingkat Inflasi (IHK), Tingkat Suku Bunga (SBI), Return On Asset (ROA) dan Non Performing Financing (NPF), yang disajikan pada Tabel 4.1, sebagai berikut:

Tabel 4.1

\section{Descriptive Statistics}

\begin{tabular}{|l|r|r|r|r|r|}
\hline & \multicolumn{1}{|c|}{ N } & Minimum & Maximum & \multicolumn{1}{c|}{ Mean } & Std. Deviation \\
\hline IPI & 32 & 93.50 & 131.90 & 110.2812 & 11.82440 \\
IHK & 36 & 2.59 & 11.96 & 5.9197 & 2.33108 \\
SBI & 35 & 5.75 & 9.42 & 6.9960 & .91048 \\
ROA & 25 & 1.00 & 223.00 & 20.1600 & 61.06327 \\
NPF & 33 & 1.00 & 134.00 & 11.3333 & 28.74746 \\
Valid N (listwise) & 21 & & & & \\
\hline
\end{tabular}

Nilai Tingkat Pertumbuhan Ekonomi (IPI) dari Bank Syariah Mandiri selama tahun 2008 hingga 2016 diperoleh nilai rata - rata sebesar 110.2812 dengan standart deviation sebesar 11.82440, nilai maksimum sebesar 131.90 yang diperoleh pada

\footnotetext{
${ }^{18}$ Faisal Basri and Haris Munandar, Lanskap Ekonomi Indonesia: Kajian Dan Renungan Terhadap Masalah-Masalah Struktural, Transformasi Baru Dan Prospek Perekonomian Indonesia (Jakarta: Kencana, 2009).53 19 Ibid.61
} 
tahun 2016 Triwulan II. Dan nilai minimum diperoleh sebesar 93.50 pada tahun 2008 Triwulan IV.

Nilai Tingkat Inflasi (IHK) dari Bank Syariah Mandiri selama tahun 2008 hingga 2016 diperoleh nilai rata - rata sebesar 5.9197 dengan standart deviation sebesar 2.33108, nilai maksimum sebesar 11.96 yang diperoleh pada tahun 2008 Triwulan III. Dan nilai minimum diperoleh sebesar 2.59 pada tahun 2008 Triwulan IV.

Nilai Tingkat Suku Bunga (SBI) dari Bank Syariah Mandiri selama tahun 2008 hingga 2016 diperoleh nilai rata rata sebesar 6.9960 dengan standart deviation sebesar 0.91048 , nilai maksimum sebesar 9.42 yang diperoleh pada tahun 2008 Triwulan IV. Dan nilai minimum diperoleh sebesar 5.75 pada tahun 2012 Triwulan II - IV.

Nilai Return On Asset dari Bank Syariah Mandiri selama tahun 2008 hingga 2016 diperoleh nilai rata - rata sebesar 20.1600 dengan standart deviation sebesar 61.06327, Nilai maksimum sebesar 223.00 yang diperoleh pada tahun 2009 Triwulan IV. Dan nilai minimum diperoleh sebesar 1.00.

Nilai Non Performing Financing (NPF) dari Bank Syariah Mandiri selama tahun 2008 hingga 2016 diperoleh nilai rata rata sebesar 11.3333 dengan standart deviation sebesar 28.74746, Nilai maksimum sebesar 134.00 yang diperoleh pada tahun 2009 Triwulan IV. Dan nilai minimum diperoleh sebesar 1.00 .

\section{Analisis Data}

Analisis data yang digunakan adalah Regresi Linear Berganda dengan menggunakan program aplikasi SPSS 23.0, karena untuk menganalisis pengaruh variabel bebas (Tingkat Pertumbuhan Ekonomi (IPI), Tingkat Inflasi (IHK), dan Tingkat Suku Bunga (SBI)) terhadap variabel terikat Return On Asset (ROA) dan Non Performing Financing (NPF). Adapun tahapan dari analisis Regresi Linear Berganda, adalah sebagai berikut:

1. Persamaan Regresi Linear Berganda 
Analisis regresi linear berganda ini bertujuan untuk meneliti bagaimana pengaruh masing-masing variabel bebas Tingkat Pertumbuhan Ekonomi (IPI), Tingkat Inflasi (IHK), dan Tingkat Suku Bunga (SBI)) terhadap variabel terikat Return On Asset (ROA) dan Non Performing Financing (NPF) pada penelitian ini. peneliti akan menyajikan hasil pengolahan data dengan menggunakan program SPSS ver. 23.0 for windows diperoleh hasil dalam Tabel 4.2.

Tabel 4.2.

Koefisien Regresi Linier Berganda Persamaan 1 ROA

\begin{tabular}{|c|c|}
\hline \multicolumn{1}{|c|}{ Variabel Penelitian } & $\begin{array}{c}\text { Koefisien } \\
\text { Regresi }\end{array}$ \\
\hline Tingkat Pertumbuhan Ekonomi (IPI) & -1.945 \\
\hline Tingkat Inflasi (IHK) & -17.998 \\
\hline Tingkat Suku Bunga (SBI) & 21.956 \\
\hline R Square $=0.271$ & Sig. $=0.029$ \\
\hline Konstanta $=189.734$ & F hit $=3.469$ \\
\hline R $=0.521$ & \\
\hline Sun
\end{tabular}

Sumber: Lampiran 4, Data Diolah (2018)

Dari data Tabel 4.2 di atas persamaan regresi yang didapat adalah: $Y=189.734$ - 1.945 IPI - 17.998 IHK + 21.956 SBI. Dari persamaan regresi linier berganda tersebut, dapat dijelaskan sebagai berikut:

a. Konstanta $(\alpha)=189.734$

Menunjukkan besarnya nilai variabel tergantung akan memiliki nilai sebesar 189.734, berarti nilai Return On Asset (ROA) akan naik sebesar 189.734, jika variabel bebas memiliki nilai sama dengan nol.

b. $\beta_{1}=-1.945$

Menunjukkan apabila variabel Tingkat Pertumbuhan Ekonomi (IPI) mengalami peningkatan sebesar satu persen maka akan terjadi penurunan pada variabel Return On Asset (ROA) sebesar 1.945. Sebaliknya, apabila variabel Tingkat Pertumbuhan Ekonomi (IPI) mengalami penurunan sebesar satu persen, maka akan terjadi peningkatan pada variabel Return On Asset (ROA) 
sebesar 1.945. Dengan asumsi besarnya variabel lain tidak berubah atau konstan.

c. $\beta_{2}=-17.998$

Menunjukkan apabila variabel Tingkat Inflasi (IHK) mengalami peningkatan sebesar satu persen maka akan terjadi penurunan pada variabel Return On Asset (ROA) sebesar 17.998. Sebaliknya, apabila variabel Tingkat Inflasi (IHK) mengalami penurunan sebesar satu persen, maka akan terjadi peningkatan pada variabel Return On Asset (ROA) sebesar 17.998. Dengan asumsi besarnya variabel lain tidak berubah atau konstan.

d. $B_{3}=21.956$

Menunjukkan apabila variabel Tingkat Suku Bunga (SBI) mengalami peningkatan sebesar satu persen, maka akan terjadi peningkatan pada variabel Return On Asset (ROA) sebesar 21.956. Sebaliknya, apabila variabel Tingkat Suku Bunga (SBI) mengalami penurunan sebesar satu persen, maka akan terjadi penurunan pada variabel Tingkat Suku Bunga (SBI) sebesar 21.956. Dengan asumsi besarnya variabel lain tidak berubah atau konstan.

Tabel 4.3

Koefisien Regresi Linier Berganda Persamaan 2 NPF

\begin{tabular}{|l|c|}
\hline Variabel Penelitian & $\begin{array}{c}\text { Koefisien } \\
\text { Regresi }\end{array}$ \\
\hline Tingkat Pertumbuhan Ekonomi (IPI) & -0.886 \\
\hline Tingkat Inflasi (IHK) & -9.291 \\
\hline Tingkat Suku Bunga (SBI) & 11.302 \\
\hline R Square $=0.305$ & Sig. $=0,022$ \\
\hline Konstanta =86.596 & F hit $=3.805$ \\
\hline R $=0.552$ & \\
\hline
\end{tabular}

Sumber:Lampiran 4, Data Diolah (2018)

Dari data Tabel 4.3 di atas persamaan regresi yang didapat adalah: $\mathbf{Y}=86.596-0.886$ IPI -9.291 IHK + 11.302 SBI. Dari persamaan regresi linier berganda tersebut, dapat dijelaskan sebagai berikut:

a. Konstanta $(\alpha)=86.596$ 
Menunjukkan besarnya nilai variabel tergantung akan memiliki nilai sebesar 86.596, berarti nilai Non Performing Financing (NPF) akan naik sebesar 189.734, jika variabel bebas memiliki nilai sama dengan nol.

b. $\beta_{1}=-0.886$

Menunjukkan apabila variabel Tingkat Pertumbuhan Ekonomi (IPI) mengalami peningkatan sebesar satu persen maka akan terjadi penurunan pada variabel Non Performing Financing (NPF) sebesar 0.886. Sebaliknya, apabila variabel Tingkat Pertumbuhan Ekonomi (IPI) mengalami penurunan sebesar satu persen, maka akan terjadi peningkatan pada variabel Non Performing Financing (NPF) sebesar 0.886. Dengan asumsi besarnya variabel lain tidak berubah atau konstan.

c. $\beta_{2}=-9.291$

Menunjukkan apabila variabel Tingkat Inflasi (IHK) mengalami peningkatan sebesar satu persen maka akan terjadi penurunan pada variabel Non Performing Financing (NPF) sebesar 9.291. Sebaliknya, apabila variabel Tingkat Inflasi (IHK) mengalami penurunan sebesar satu persen, maka akan terjadi peningkatan pada variabel Non Performing Financing (NPF) sebesar 9.291. Dengan asumsi besarnya variabel lain tidak berubah atau konstan.

d. $\mathrm{B}_{3}=11.302$

Menunjukkan apabila variabel Tingkat Suku Bunga (SBI) mengalami peningkatan sebesar satu persen, maka akan terjadi peningkatan pada variabel Non Performing Financing (NPF) sebesar 11.302. Sebaliknya, apabila variabel Tingkat Suku Bunga (SBI) mengalami penurunan sebesar satu persen, maka akan terjadi penurunan pada variabel Tingkat Suku Bunga (SBI) sebesar 11.302. Dengan asumsi besarnya variabel lain tidak berubah atau konstan. 


\section{Koefisien Korelasi berganda dan Koefisien Determinasi}

Hasil analisis koefisien korelasi dan koefisien determinasi, dapat dilihat pada Tabel 4.4 dan Tabel 4.5, sebagai berikut:

Tabel 4.4

Koefisien Korelasi Dan Koefisien Determinasi Persamaan 1 ROA

\begin{tabular}{|c|c|c|}
\hline Model & $\mathbf{R}$ & $\mathbf{R}^{2}$ (Square) \\
\hline 1 & 0.521 & 0.271 \\
\hline \multicolumn{3}{|c|}{ Sumber : Lampiran 4, Data Diolah (2018) } \\
\hline
\end{tabular}

Nilai koefisien korelasi (R) menunjukkan seberapa erat hubungan antara variabel bebas Tingkat Pertumbuhan Ekonomi (IPI), Tingkat Inflasi (IHK), dan Tingkat Suku Bunga (SBI), dengan variabel terikat Return On Asset (ROA), besarnya nilai koefisien korelasi adalah 0.521. Nilai tersebut menunjukkan bahwa hubungan variabel Tingkat Pertumbuhan Ekonomi (IPI), Tingkat Inflasi (IHK), dan Tingkat Suku Bunga (SBI) dengan variabel Return On Asset (ROA) adalah cukup erat atau cukup kuat.

Nilai koefisien determinasi digunakan untuk mengukur seberapa jauh kemampuan model dalam menerangkan variasi variabel tak bebas (Y1) yaitu 0,271. Hal ini berarti sebesar 27.1\% Return On Asset (ROA) dapat dijelaskan oleh variabel Tingkat Pertumbuhan Ekonomi (IPI), Tingkat Inflasi (IHK), dan Tingkat Suku Bunga (SBI). Sedangkan sisanya $72.9 \%$ dipengaruhi oleh variabel lain diluar model yang diteliti.

Tabel 4.5

Koefisien Korelasi Dan Koefisien Determinasi Persamaan 2 NPF

\begin{tabular}{|c|c|c|}
\hline Model & $\mathbf{R}$ & $\mathbf{R}^{2}$ (Square) \\
\hline 1 & 0.552 & 0.305 \\
\hline
\end{tabular}

Sumber : Lampiran 4, Data Diolah (2018)

Berdasarkan Tabel 4.5 dapat diketahuin Nilai koefisien korelasi (R) menunjukkan seberapa erat hubungan antara variabel bebas Tingkat Pertumbuhan Ekonomi (IPI), Tingkat Inflasi (IHK), dan Tingkat Suku Bunga (SBI), dengan variabel terikat Return On Asset (ROA), besarnya nilai koefisien korelasi adalah 0.552. Nilai tersebut menunjukkan bahwa hubungan variabel Tingkat Pertumbuhan Ekonomi (IPI), Tingkat Inflasi 
(IHK), dan Tingkat Suku Bunga (SBI) dengan variabel Non Performing Financing (NPF) adalah cukup erat atau cukup kuat.

Nilai koefisien determinasi digunakan untuk mengukur seberapa jauh kemampuan model dalam menerangkan variasi variabel tak bebas (Y) yaitu 0,271. Hal ini berarti sebesar 30.5\% Non Performing Financing (NPF) dapat dijelaskan oleh variabel Tingkat Pertumbuhan Ekonomi (IPI), Tingkat Inflasi (IHK), dan Tingkat Suku Bunga (SBI). Sedangkan sisanya 69.5\% dipengaruhi oleh variabel lain diluar model yang diteliti.

\section{Pengaruh Tingkat Pertumbuhan Ekonomi (IPI) Terhadap Return On Asset (ROA) Pada Bank Syariah Mandiri Tahun $2008-2016$}

IPI yaitu sebuah indikator ekonomi yang mengukur produksi output riil. Hal ini dinyatakan sebagai output riil dengan tahun dasar 2000. IPI menggambarkan persentase dari produksi output riil. Kenaikan IPI merupakan salah satu sinyal kondisi makroekonomi sedang baik.

Berdasarkan hasil penelitian ini menunjukkan bahwa variabel Tingkat Pertumbuhan Ekonomi (IPI) memiliki pengaruh negatif terhadap Return On Asset (ROA) pada Bank Syariah Mandiri periode 2008-2016, hal ini dapat dilihat pada Tabel 4.13 besarnya nilai thitung variabel bebas $\left(\mathrm{X}_{1}\right)$ adalah 2.197 dengan nilai signifikansi 0.036 , berarti lebih kecil dari $(\alpha)$ $=0.05$ (5\%). Variabel Tingkat Pertumbuhan Ekonomi (IPI) dengan koefisien regresi sebesar -1.945 yang berarti semakin tinggi Tingkat Pertumbuhan Ekonomi (IPI), maka semakin turun nilai Return On Asset (ROA).

Hasil penelitian mendukung pendapat Aviliani ${ }^{20}$ yang mengemukakan bahwa Indeks Produksi Industri (IPI) sebagai proksi dari pendapatan nasional yang memiliki hubungan kuat dengan hamper semua indikator kinerja bank.

\footnotetext{
${ }^{20}$ Aviliani. dkk, “The Impact of Macroeconomic Condition on The Bank's Performance in Indonesia," Bulletin Ekonomi Moneter dan Perbankan Vol.17 No. (n.d.): 398.
} 
Pertumbuhan ekonomi dapat meningkatkan cash flow bank dengan cara meningkatkan permintaan pembiayaan oleh perusahaan dan rumah tangga. Selama periode pertumbuhan ekonomi yang kuat permintaan pembiayaan cenderung meningkat. Karena pembiayaan cederung menghasilkan keuntungan lebih baik dari pada investasi surat-surat berharga, maka expected cash flow akan lebih tinggi. Alasan lain dari tingginya cash flow adalah semakin sedikit tingkat risiko default yang terjadi selama masa pertumbuhan ekonomi yang kuat (Madura, dalam Ihsan ${ }^{21}$ ).

Hasil penelitian ini bertolak belakang dengan studi yang dilakukan oleh Nugraheni ${ }^{22}$ Pada variabel ROE dan ROA dampak guncangan direspon dengan positif. Peningkatan ROE disebabkan oleh perbaikan kondisi ekonomi yang ditandai dengan meningkatnya pertumbuhan produksi. Pertumbuhan ekonomi ini akan menyebabkan masyarakat memiliki cukup dana untuk mengembalikan pinjaman kepada bank syariah, sehingga laba bank syariah meningkat. Respon ini akan stabil pada periode 44 sampai akhir periode amatan dan nilainya berkisar antara 0.1 persen. Akibat adanya peningkatan kemampuan masyarakat dalam melakukan pengembalian kepada perbankan syariah, maka laba perbankan syariah mengalami peningkatan pula. Pada awal periode yaitu periode satu sampai 13 guncangan IPI terhadap ROA merespon positif, namun stelah periode tersebut hingga akhir amatan estimasi responnya negatif dan mulai stabil pada periode 25 dengan nilai respon berkisar antara 0.07 persen.

\section{Pengaruh Tingkat Inflasi (IHK) Terhadap Return On Asset (ROA) Pada Bank Syariah Mandiri Tahun 2008 - 2016}

\footnotetext{
${ }^{21}$ Muntoha Ihsan, "Pengaruh Gross Domestic Product, Inflasi, Dan Kebijakan Jenis Pembiayaan Terhadap Rasio Non Performing Financing Bank Umum Syariah Di Indonesia Periode 2005 Sampai 2010" (Tesis Universitas Diponegoro Semarang, 2011).

22 Sri Retno Wahyu Nugraheni, "Analisis Daya Tahan Perbankan Syariah Terhadap Fluktuasi Ekonomi Di Indonesia” (Tesis Institut Pertanian Bogor, 2011).
} 
Inflasi merupakan peningkatan tingkat harga umum dalam suatu perekonomian yang berlangsung secara terus menerus dari waktu ke waktu. Kecenderungan harga barangbarang yang semakin meningkat (Inflasi) akan berpengaruh terhadap kinerja keuangan pada sector perbankan. Secara teori, inflasi berpengaruh terhadap dunia perbankan sebagai salah satu institusi keuangan. Hal tersebut sesuai dengan hasil penelitian ini yang menemukan variabel Tingkat Inflasi (IHK) memiliki pengaruh negatif terhadap Return On Asset (ROA) pada Bank Syariah Mandiri periode 2008-2016, hal ini dapat dilihat pada Tabel 4.13 besarnya nilai thitung variabel bebas $\left(\mathrm{X}_{2}\right)$ adalah -2.493 dengan nilai signifikansi 0.019 , berarti lebih kecil dari $(\alpha)=0.05$ (5\%). Variabel Tingkat Inflasi (IHK) dengan koefisien regresi sebesar -17.998 yang berarti semakin tinggi Tingkat Inflasi (IHK), maka semakin turun nilai Return On Asset (ROA).

Hasil penelitian mendukung pendapat Sukirno ${ }^{23}$ Tingkat bunga meningkat sehingga mengurangi investasi, untuk menghindati penurunan dari nilai modal yang dipinjamkan. Makin tinggi nilai inflasi maka makin tinggi pula tingkat bunganya. Tingkat bunga yang tinggi akan mengurangi kemauan pemilik modal untuk mengembangkan sektor-sektor profuktif. Apabila dikaitkan dengan kinerja bank, maka dengan redahnya investasi maka akan menghambat likuditas bank, penyaluran dana jadi menurun dan secara otomatis profit juga akan lebih kecil jika dana yang disalurkan semakin sedikit.

Hasil penelitian ini sejalan penelitian Nugraheni yang menemukan dampak guncangan pada sisi penawaran melalui CPI memiliki respon yang negatif pada NPF, sedangkan pada variabel ROE dan ROA responnya berupa respon positif. Tekanan inflasi dari sisi biaya merupakan sumber inflasi yang signifikan dalam pembentukkan harga di Indonesia. Kondisi ini dimanfaatkan perusahaan untuk mengambil keuntungan

23 Sadono Sukirno, Pengantar Teori Ekonomi Makro (Jakarta: Raja Grafindo, 1998).33 
dengan cara menaikkan harga jual barang dan jasa sehingga pendapatan perusahaan meningkat yang diikuti dengan meningkatnya kemampuan perusahaan dalam mengembalikan pembiayaan bank. Hal ini menyebabkan nilai laba bersih bank syariah mengalami peningkatan. Respon negatif hanya berlangsung pada periode empat, selebihnya respon positif berlangsung hingga akhir amatan.

Hasil penelitian ini sejalan dengan temuan penelitian $\mathrm{Al}$ Banna ${ }^{24}$ yang menemukan respon stabilitas perbankan syariah terhadap guncangan inflasi direspon secara negatif selama periode penelitian. Inflasi memiliki kontribusi $1.146671 \%$ terhadap stabilitas perbankan syariah.

\section{Pengaruh Tingkat Suku Bunga (SBI) Terhadap Return On Asset (ROA) Pada Bank Syariah Mandiri Tahun 2008 - 2016}

Suku bunga Bank Indonesia (BI Rate) ${ }^{25}$ adalah suku bunga acuan yang mencerminkan sikap kebijakan moneter yang ditetapkan oleh Bank Indonesia sebagai otoritas moneter dan diumumkan kepada publik.

Berdasarkan hasil penelitian ini ditemukan bahwa Tingkat Suku Bunga (SBI) tidak memiliki pengaruh signifikan negatif terhadap Return On Asset (ROA) pada Bank Syariah Mandiri periode 2008-2016, hal ini dapat dilihat pada Tabel 4.13 besarnya nilai thitung variabel bebas $\left(\mathrm{X}_{3}\right)$ adalah 1.240 dengan nilai signifikansi 0.225 , berarti lebih besar dari $(\alpha)=$ 0.05 (5\%). Variabel Tingkat Suku Bunga (SBI) dengan koefisien regresi sebesar 21.956 yang berarti semakin tinggi Tingkat Suku Bunga (SBI), maka semakin meningkat nilai Return On Asset (ROA).

\footnotetext{
24 Hasan Al Banna, “Analisis Komparasi Stabilitas Perbankan Syariah Dan Perbankan Konvensional Di Indonesia Pasca Krisis Keuangan Tahun 2007" (Tesis UIN Sunan Kalijaga, 2016).

${ }^{25}$ www.bi.go.id
} 
Hasil penelitian tidak sejalan dengan temuan penelitian Dwijayanti ${ }^{26}$ yang mengemukakan bahwa secara tidak langsung BI rate mempengaruhi kinerja keuangan perbankan melalui suku bunga pokok perbankan. Karena apabila BI rate naik, maka suku bunga simpanan dan pinjaman akan naik juga. Hal tersebut mengakibatkan masyarakat lebih menaruh uangnya di Bank dalam bentuk simpanan dengan ekspektasi mendapat bunga yang tinggi daripada meminjam uang. Hal ini menyebabkan penurunan penyaluran kredit dan pendapatan bank dari sektor kredit akan berkurang sehingga penurunan profit.

Hasil penelitian bertolak belakang dengan pendapat Aviliani yang mengemukakan secara umum suku bunga kebijakan (BI Rate) merupakan variabel makro yang direspon besar oleh mayoritas indikator kinerja bank. Bi Rate merupakan instrument paling potensial yang dimiliki Bank Indonesia untuk menjaga kestabilan sektor keuangan, khususnya perbankan.

Tidak sejalan pula dengan penelitian Ihsan yang menemukan bahwa variabel SBI tetap menjadi faktor yang paling besar pengaruhnya terhadap perubahan ROA yaitu sebesar 13.61233 persen. Hal ini, tentu saja sesuai dengan hipotesis yang diharapkan yang berarti SBI berkontribusi nyata terhadap perubahan ROA.

Demikian pula dengan hasil studi Al Banna yang menemukan bahwa Guncangan pada variable Bi Rate direspon positif pada periodel awal oleh stabilitas perbankan syariah, dan trend selanjutnya respon yang ditunjukan berfluktuatuif, periode tertentu direspon secara negatif dan periode yang lain direspon secara positif kembali. Namun trend yang terajdi pada akhir periode penelitian BI Rate direspon secara positif. BI Rate

\footnotetext{
${ }^{26}$ Febriana Dwijayanti and Naomi, "Analisis Pengaruh Inflasi, BI Rate Dan Nilai Tukar Mata Uang Terhadap Profitabilitas Bank Periode 2003 - 2007," Jurnal Karisma Vol.3 (2): (2009): 95.
} 
berkontribusi sebesar $2.386047 \%$ terhadap stabilitas perbankan syariah.

\section{Pengaruh Tingkat Pertumbuhan Ekonomi (IPI) Terhadap Non Performing Financing (NPF) Pada Bank Syariah Mandiri Tahun 2008 - 2016}

IPI yaitu sebuah indikator ekonomi yang mengukur produksi output riil. Hal ini dinyatakan sebagai output riil dengan tahun dasar 2000. IPI menggambarkan persentase dari produksi output riil. Kenaikan IPI merupakan salah satu sinyal kondisi makroekonomi sedang baik. Sedangkan NPF merupakan rasio pembiayaan bermasalah suatu bank syariah terhadap total seluruh pembiayaan yang diberikan bank. Apabila nilai NPF semakin besar, maka bank dalam keadaan tidak sehat.

Dalam kaitannya dengan kredit bermasalah, dalam kondisi resesi (terlihat dari penurunan IPI) dimana terjadi penurunan penjualan dan pendapatan perusahaan, maka akan mempengaruhi kemampuan perusahaan dalam mengembalikan pinjamannya. Hal ini akan menyebabkan bertambahnya outstanding kredit non lancar (Rahmawulan ${ }^{27}$ ). Sementara itu Nasution ${ }^{28}$ mengemukakan bahwa ketika IPI meningkat secara teori terjadi peningkatan transaksi ekonomi, dunia bisnis menggelihat, sehingga non performing financing turun.

Berdasarkan hasil penelitian ini menunjukkan bahwa variabel Tingkat Pertumbuhan Ekonomi (IPI) memiliki pengaruh negatif terhadap Non Performing Financing (NPF) pada Bank Syariah Mandiri periode 2008-2016, hal ini dapat

\footnotetext{
${ }^{27}$ Yunis Rahmawulan, "Perbandingan Faktor Penyebab Timbulnya NPL Dan NPF Pada Perbankan Konvensional Dan Syariah Di Indonesia” (Tesis Universitas Indonesia, 2008).

${ }^{28}$ Mustafa Edwin Nasution and Ranti Wiliasih, "Profit Sharing Dan Morl Hazard Dalam Penyaluran Dana Pihak Ketiga Bank Umum Syariah Di Indonesia," Jurnal Ekonomi dan Pembangunan Indonesia Vo.VIII No (n.d.): 105-129.
} 
dilihat pada Tabel 4.13 besarnya nilai thitung variabel bebas $\left(\mathrm{X}_{1}\right)$ adalah -2.141 dengan nilai signifikansi 0.042, berarti lebih kecil dari $(\alpha)=0.05(5 \%)$. Variabel Tingkat Pertumbuhan Ekonomi (IPI) dengan koefisien regresi sebesar -0.886 yang berarti semakin tinggi Tingkat Pertumbuhan Ekonomi (IPI), maka semakin turun nilai Non Performing Financing (NPF).

Hasil penelitian mendukung pendapat Nugraheni yang mengemukakan Guncangan pada sisi permintaan dari IPI menyebabkan keinginan untuk mengembalikan pembiayaan yang diberikan bank syariah meningkat, sehingga nilai NPF akan turun. Nilai NPF akan mulai stabil pada periode 12 hingga akhir estimasi dengan kisaran respon 0.03 persen.

\section{Pengaruh Tingkat Inflasi (IHK) Terhadap Non Performing Financing (NPF) Pada Bank Syariah Mandiri Tahun 2008 - 2016}

Menurut Bank Indonesia, Inflasi dapat diartikan sebagai meningkatnya harga-harga secara umum dan terus-menerus. Kenaikan harga dari satu atau dua barang saja tidak dapat disebut inflasi kecuali bila kenaikan itu meluas (atau mengakibatkan kenaikan harga) pada barang lainnya. Inflasi adalah indikator untuk melihat tingkat perubahan dan dianggap terjadi jika proses kenaikan harga berlangsung secara terus-menerus dan saling memengaruhi. Kenaikan harga-harga ini memberikan tekanan pada ekonomi masyarakat terutama bagi mereka yang menjadi debitur (mudharib) perbankan syariah.

Hasil penelitian ini yang menemukan variabel Tingkat Inflasi (IHK) memiliki pengaruh negatif terhadap Non Performing Financing (NPF) pada Bank Syariah Mandiri periode 2008-2016, hal ini dapat dilihat pada Tabel 4.13 besarnya nilai thitung variabel bebas $\left(\mathrm{X}_{2}\right)$ adalah -2.780 dengan nilai signifikansi 0.010 , berarti lebih kecil dari $(\alpha)=0.05(5 \%)$. Variabel Tingkat Inflasi (IHK) dengan koefisien regresi sebesar -9.291 yang berarti semakin tinggi Tingkat Inflasi (IHK), maka semakin turun nilai Non Performing Financing (NPF). Hal tersebut menunjukkan bahwa Jika inflasi terjadi pada saat 
pendapatan masyarakat tetap atau menurun, maka hal ini dapat memperparah risiko pembiayaan yang dihadapi perbankan syariah, sebab kemampuan pengembalian pembiayaan oleh debitur turut menurun. Sebelum inflasi terjadi, seorang debitur sanggup untuk membayar angsurannya. Ketika inflasi, harga-harga mengalami peningkatan yang cukup tinggi, sedangkan penghasilan debitur tersebut tidak mengalami peningkatan.

Hal ini sejalan dengan pendapat Adam ${ }^{29}$ yang menunjukkan Peningkatan NPL merupakan akumulasi dari beberapa permasalahan antara lain imbas negatif krisis keuangan global tidak hanya menurunkan aggregate demand, tapi juga memaksa perusahaan masuk ke iklim persaingan yang semakin ketat. Keadaan ini membuat perusahaan mengalami kesulitan dalam mempertahankan pasar dan memperburuk proses usaha. Konsekuensinya pendapatan perusahaan menurun dan neraca keuangan mengalami pembusukan. Hal ini kemudian membuat perusahaan mengalami penurunan kemampuan dalam membayar angsuran pinjaman ke perbankan.

Hasil penelitian sejalan dengan penelitian Nugraheni yang mengemukakan bahwa Tekanan inflasi dari sisi biaya merupakan sumber inflasi yang signifikan dalam pembentukkan harga di Indonesia. Kondisi ini dimanfaatkan perusahaan untuk mengambil keuntungan dengan cara menaikkan harga jual barang dan jasa sehingga pendapatan perusahaan meningkat yang diikuti dengan meningkatnya kemampuan perusahaan dalam mengembalikan pembiayaan bank. Hal ini menyebabkan nilai laba bersih bank syariah mengalami peningkatan. Respon negatif hanya berlangsung pada periode empat, selebihnya respon positif berlangsung hingga akhir amatan estimasi dan mulai stabil pada periode 47 pada kisaran nilai respon 0.2 persen. Dampak terhadap variabel NPF negatif dikarenakan

${ }^{29}$ Latif Adam, Kredit Bermasalah, Penyebab Dan Dampaknya (Pusat

Penelitian Ekonomi (P2E) LIPI, 2009).61 
meningkatnya kemampuan perusahaan dalam melakukan pengembalian terhadap pembiayaan bank, sehingga nilai NPF menjadi turun.

\section{Pengaruh Tingkat Suku Bunga (SBI) Terhadap Non Performing Financing (NPF) Pada Bank Syariah Mandiri Tahun 2008 - 2016}

Bank Indonesia mendefinisikan BI Rate sebagai suku bunga kebijakan yang mencerminkan sikap atau stance kebijakan moneter yang ditetapkan oleh Bank Indonesia dan diumumkan kepada publik. Pada bank konvensional, terjadinya peningkatan BI Rate biasanya diikuti dengan peningkatan suku bunga kredit. Hal ini dikarenakan BI Rate merupakan suku bunga yang dijadikan acuan dalam sistem operasional bank konvensional, sedangkan bank syariah menggunakan sistem operasional dengan berpedoman Al Quran dan Hadits yang tidak mengenal sistem kredit dan bunga dalam kegiatan usahanya.

Berdasarkan hasil penelitian ini ditemukan bahwa Tingkat Suku Bunga (SBI) tidak memiliki pengaruh signifikan negatif terhadap Non Performing Financing (NPF) pada Bank Syariah Mandiri periode 2008-2016, hal ini dapat dilihat pada Tabel 4.13 besarnya nilai thitung variabel bebas $\left(\mathrm{X}_{3}\right)$ adalah 1.368 dengan nilai signifikansi 0.183 , berarti lebih besar dari $(\alpha)=$ 0.05 (5\%). Variabel Tingkat Suku Bunga (SBI) dengan koefisien regresi sebesar 11.302 yang berarti semakin tinggi Tingkat Suku Bunga (SBI), maka semakin meningkat nilai Non Performing Financing (NPF).

BI Rate dalam perbankan syariah berperan sebagai pembanding. Saat BI Rate naik, maka terjadi peningkatan daya saing bank syariah dimana nisbah bagi hasil bank syariah (profit/loss sharing) mampu bersaing dengan tingkat bunga pinjaman bank konvensional yang meningkat. Dengan kata lain, dengan adanya peningkatan BI Rate, produk pembiayaan oleh bank syariah akan semakin kompetitif. Margin atau nisbah bagi hasil bank syariah yang ditentukan oleh kapasitas usaha atau laba/rugi debitur tidak dapat naik begitu saja, maka margin 
tersebut akan lebih bersaing terhadap suku bunga kredit bank konvensional.

\section{Penutup}

Berdasarkan hasil penelitian dan pembahasan pada bab sebelumnya dapat ditarik beberapa kesimpulan guna menjawab rumusan masalah. Beberapa kesimpulan tersebut terdiri dari:

1. Tingkat Pertumbuhan Ekonomi (IPI) berpengaruh negatif signifikan terhadap Return On Asset (ROA) pada Bank Syariah Mandiri periode 2008-2016.

2. Tingkat Inflasi (IHK) berpengaruh negatif signifikan terhadap Return On Asset (ROA) pada Bank Syariah Mandiri periode 2008-2016.

3. Tingkat Suku Bunga (SBI) tidak berpengaruh signifikan terhadap Return On Asset (ROA) pada Bank Syariah Mandiri periode 2008-2016.

4. Tingkat Pertumbuhan Ekonomi (IPI) berpengaruh negatif signifikan terhadap Non Performing Financing (NPF) pada Bank Syariah Mandiri periode 2008-2016.

5. Tingkat Inflasi (IHK) berpengaruh negatif signifikan terhadap Non Performing Financing (NPF) pada Bank Syariah Mandiri periode 2008-2016.

6. Tingkat Suku Bunga (SBI) tidak berpengaruh signifikan terhadap Non Performing Financing (NPF) pada Bank Syariah Mandiri periode 2008-2016.

\section{Daftar Pustaka}

13/1/PBI/2011, Peraturan Bank Indonesia No. Peningkatan Tingkat Kesehatan Bank Umum Pasal 9 (7), n.d.

Adam, Latif. Kredit Bermasalah, Penyebab Dan Dampaknya. Pusat Penelitian Ekonomi (P2E) LIPI, 2009.

Aviliani. dkk. "The Impact of Macroeconomic Condition on The Bank's Performance in Indonesia." Bulletin Ekonomi Moneter dan Perbankan Vol.17 No. (n.d.): 398.

Al Banna, Hasan. "Analisis Komparasi Stabilitas Perbankan Syariah Dan Perbankan Konvensional Di Indonesia Pasca Krisis Keuangan Tahun 2007.” Tesis UIN Sunan Kalijaga, 
2016.

Basri, Faisal, and Haris Munandar. Lanskap Ekonomi Indonesia: Kajian Dan Renungan Terhadap Masalah-Masalah Struktural, Transformasi Baru Dan Prospek Perekonomian Indonesia. Jakarta: Kencana, 2009.

Boediono. Ekonomi Moneter. Yogyakarta: BPFE, 1998.

Dornbusch, R. Macroeconomics. New York: Mc Graw Hill Inc, 2008.

Dwijayanti, Febriana, and Naomi. "Analisis Pengaruh Inflasi, BI Rate Dan Nilai Tukar Mata Uang Terhadap Profitabilitas Bank Periode 2003 - 2007." Jurnal Karisma Vol.3 (2): (2009): 95.

H, Rismon, and Henny Setyo L. "Pengaruh Faktor Intenal Dan Eksternal Bank Terhadap Kinerja Bank Di Perusahaan Perbankan Di Bursa Efek Indonesia." Jurnal Manajemen Trisakti Vol2 No,1 (2015): .

Hasan, Maher, and Jemma Dridi. "The Effect of Global Crisis On Islamic and Conventional Banking: A Comparative Study." IMF Working Paper, n.d.

Humas Bank Indonesia. Krisis Global Dan Penyelamatan Atas Sistem Perbankan Indonesia. Jakarta: Bank Indonesia, 2010.

Ihsan, Muntoha. "Pengaruh Gross Domestic Product, Inflasi, Dan Kebijakan Jenis Pembiayaan Terhadap Rasio Non Performing Financing Bank Umum Syariah Di Indonesia Periode 2005 Sampai 2010." Tesis Universitas Diponegoro Semarang, 2011.

Indonesia, Bank. Laporan Tahunan, 2005-2010.

Linda. "Pengaruh Inflasi, Kurs Dan Tingkat Suku Bunga Terhadap Non Performing Loan Pada PT. Bank Tabungan Negara (PERSERO) Tbk Cabang Padang." Journal of Economic and Economic Education Vol.3 No.2 (2015): .

Mankiw, N Gregory. Makroekonomi. Jakarta: Penerbit Erlangga, 2007.

Nasional, Departemen Pendidikan. Kamus Besar Bahasa Indonesia Pusat Bahasa. Edisi ke-4. Jakarta: PT. Gramedia Pustaka Utama, 2008.

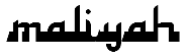


Nasution, Mustafa Edwin, and Ranti Wiliasih. "Profit Sharing Dan Morl Hazard Dalam Penyaluran Dana Pihak Ketiga Bank Umum Syariah Di Indonesia." Jurnal Ekonomi dan Pembangunan Indonesia Vo.VIII No (n.d.): .

Nugraheni, Sri Retno Wahyu. "Analisis Daya Tahan Perbankan Syariah Terhadap Fluktuasi Ekonomi Di Indonesia." Tesis Institut Pertanian Bogor, 2011.

Ongore, V.O. "The Relationsip Between Ownership Structure and Firm Performance: An Empirical Analysis of Listed Companies in Kenya." Africal Journal of Bussines Manajement (2011).

Rahmawulan, Yunis. "Perbandingan Faktor Penyebab Timbulnya NPL Dan NPF Pada Perbankan Konvensional Dan Syariah Di Indonesia." Tesis Universitas Indonesia, 2008.

Siamat, Dahlan. Manajemen Lembaga Keuangan Edisi. Jakarta: lemabaga Penerbit FE, 2001.

Sugiyo. Metode Penelitian Kuantitatif Kualitatif Dan $R \& D$. Bandung: Alfabeta, 2010.

Sukirno, Sadono. Pengantar Teori Ekonomi Makro. Jakarta: Raja Grafindo, 1998.

www.bi.go.id 